\title{
Geologic fault model based on the high-resolution seismic reflection profile and aftershock distribution associated with the 2004 Mid-Niigata Prefecture earthquake (M6.8), central Japan
}

\author{
Naoko Kato ${ }^{1}$, Tomoo Echigo ${ }^{2}$, Hiroshi Sato ${ }^{1}$, Masaaki Tateishi ${ }^{3}$, Sumiko Ogino ${ }^{1}$, Shin'ichi Sakai ${ }^{1}$, Shigeru Toda ${ }^{4}$, \\ Shin Koshiya ${ }^{5}$, Tanio Ito ${ }^{6}$, Tsuyoshi Toyoshima ${ }^{7}$, Toshifumi Imaizumi ${ }^{8}$, Hajime Kato ${ }^{9}$, and Shintaro Abe ${ }^{10}$

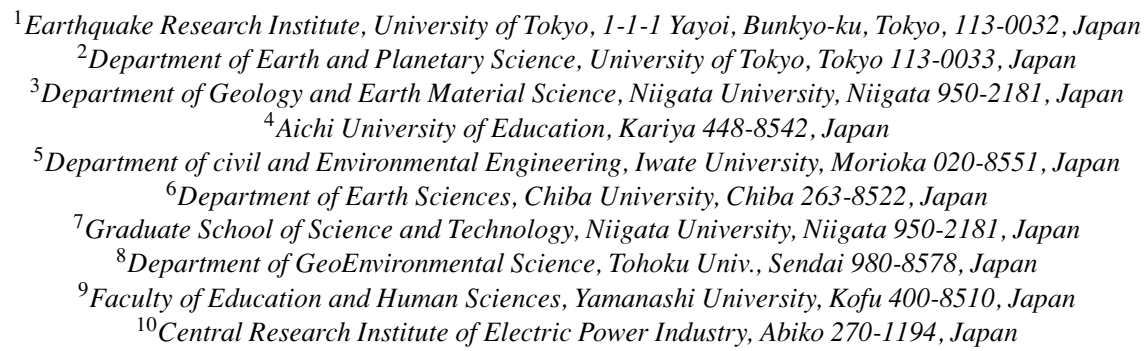

(Received February 15, 2005; Revised April 20, 2005; Accepted April 20, 2005)

\begin{abstract}
The Mid-Niigata Prefecture earthquake in 2004 ( $\mathrm{M}_{\mathrm{JMA}}$ 6.8) generated surface ruptures along the eastern rim of the Uonuma Hills. To elucidate the structural linkage between the surface ruptures and the source fault at depth, the high-resolution seismic reflection profile across the surface ruptures and nearby active faults, and the data of aftershock distribution are examined. The 5.2-km-long, high-resolution, depth-converted seismic section reveals an emergent thrust beneath the surface ruptures. A two-dimensional model of the fault geometry has been constructed based on the aftershock distribution and the shallow reflection profile. The development of the main geologic structure are well explained by forward modeling using a balanced cross-section method. In detail, the fault system generated the main shock dips at a steep angle $\left(60^{\circ}\right)$ below $5 \mathrm{~km}$ depth and more shallowly $\left(30^{\circ}\right)$ near the surface.
\end{abstract}

Key words: 2004 Mid-Niigata Prefecture earthquake, seismic reflection profile, fault model, subsurface structure, surface rupture, active fault-and-fold, balanced-cross section, central Japan.

\section{Introduction}

The 2004 Mid-Niigata Prefecture earthquake occurred on October 23, 2004. The main shock ( $\mathrm{M}_{\mathrm{JMA}}$ 6.8) was followed by a series of aftershocks, the largest of which were $\mathrm{M}_{\mathrm{JMA}} 6.0$ and $\mathrm{M}_{\mathrm{JMA}} 6.5$ events that occurred within one hour of the main shock, a $\mathrm{M}_{\mathrm{JMA}} 6.1$ event on October 27, and a $\mathrm{M}_{\mathrm{JMA}} 5.9$ event on November 8 . According to the aftershock distribution and their focal mechanisms, the source faults of the main shock and the largest aftershock are westdipping reverse faults (Hirata et al., 2005). Surface ruptures associated with this earthquake emerged on the eastern flank of the Uonuma Hills (Maruyama et al., 2005). These surface ruptures are located further east than the upward projection of the fault plane that presumably generated the main shock. This discordance possibly indicates upward-flattening thrust trajectory above the source fault at depth. Identifying structural links between the surface ruptures, active folding, and the seismogenic fault at depth is very important for the accurate evaluation of seismic hazards posed by future earthquakes (e.g. Tsusumi and Yeats,

Copy right(c) The Society of Geomagnetism and Earth, Planetary and Space Sciences (SGEPSS); The Seismological Society of Japan; The Volcanological Society of Japan; The Geodetic Society of Japan; The Japanese Society for Planetary Sciences; TERRAPUB
1999).

We focus on structural linkage between the shallow subsurface structure, the surface ruptures, and the source fault at depth, using the high-resolution seismic reflection profile across the surface ruptures and nearby active faults, and data of aftershock distribution.

\section{Geologic Setting}

The epicentral area of the 2004 mid-Niigata earthquake is located on the eastern margin of the Niigata sedimentary basin (Fig. 1), formed by rifting in the early Miocene associated with the opening of the Sea of Japan (e.g. Sato, 1994). It contains a thick $(\sim 6 \mathrm{~km})$ accumulation of Neogene sediments including volcaniclastic material (Niigata Prefectural Government, 2000). The eastern margin of the basin is bounded by the Shibata-Koide Tectonic Line (Yamashita, 1970), which separates the Neogene basin fill from the Mesozoic basement rocks to the east. The Uonuma Hills, the most severely damaged areas by this earthquake, is narrow uplifted belt since the late Neogene, and composed of unconsolidated sediments, Plio-Pleistocene Uonuma Formation (Yanagisawa et al., 1986).

The Uonuma Hills form a NNE to NE-trending anticlinorium. The largest anticline is the Higashiyama anticline, 


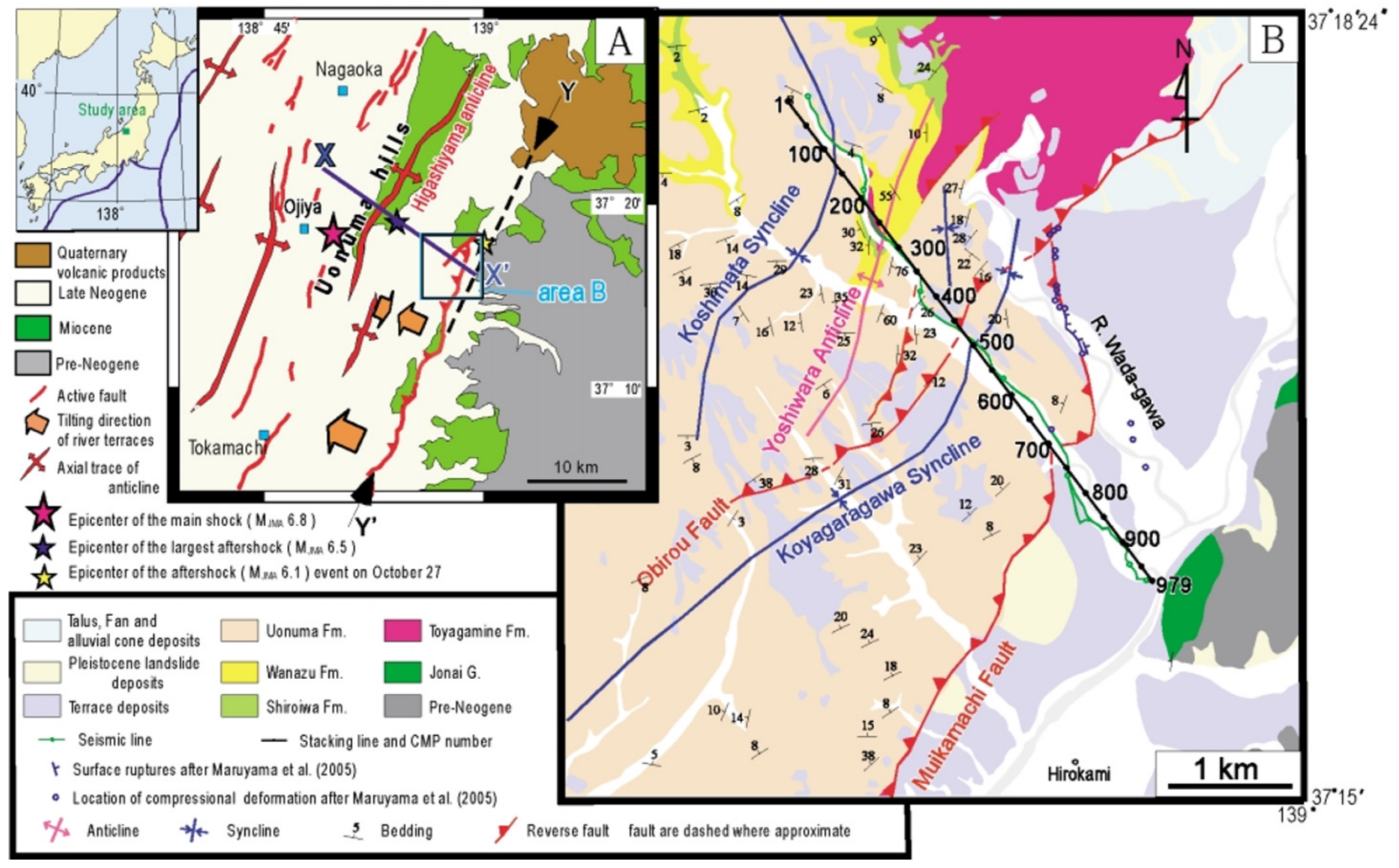

Fig. 1. (A) Generalized geologic structure around the Uonuma hills after Niigata Prefectural Government (2000). Locations of epicenter are after Hirata et al. (2005). X-X': see Fig. 5, Y-Y': Shibata-Koide tectonic line. (B) Geologic map showing the Hirokami 2004 seismic line. The geologic map is after Yanagisawa et al. (1986).

Table 1. Data acquisition parameters for the Hirokami 2004 seismic survey.

\begin{tabular}{ll}
\hline $\begin{array}{l}\text { Length of seismic line } \\
\text { Source parameters }\end{array}$ & $5.2 \mathrm{~km}$ \\
Source & $\begin{array}{l}\text { Mini-vibrator (IVI,T-15000) } \\
\text { Sweep frequency }\end{array}$ \\
Sweep length & $20 \mathrm{~s}$ \\
No. of sweeps & $5 \mathrm{or} 7$ \\
No. of shot points & 515 \\
Shot interval & $10 \mathrm{~m}$ \\
Receiver parameters & \\
Natural frequency & $10 \mathrm{~Hz}$ \\
Receiver interval & $10 \mathrm{~m}$ \\
No. of channels & 180 \\
Recording parameters & \\
Instruments & $\mathrm{JGI}, \mathrm{GDAPS}-4$ \\
Sampling interval & $2 \mathrm{~ms}$ \\
Recording length & $3 \mathrm{sec}$ \\
Standard CMP fold & 96 \\
& \\
\hline
\end{tabular}

where late Miocene volcanics and volcaniclastic sediments (Araya Formation) are exposed along the axial part. On the eastern flank of the Higashiyama anticline, Neogene sediments have been deposited as the Kawaguchi, Ushigakubi, Shiroiwa, Wanazu and Uonuma formations, in ascending order. The total thickness of the sediments is 500-2000 m and shows westward thickening.

Due to contraction since the late Neogene, NNE-NEtrending folds have developed within the Neogene sediments. According to the compilation of age and dip-angle of strata (Ohba and Kosaka, 2001), the sediments younger than 1.9 Ma shows same rate of deformation. Thus, the main phase of the shortening deformation began at ca. 2 $\mathrm{Ma}$ and has been prevailed associated with the active reverse faulting and folding (e.g. Ikeda et al., 2002).

\section{Hirokami 2004 Seismic Survey}

\subsection{Data acquisition and processing}

A 5.2-km-long seismic line was deployed across the surface ruptures (Maruyama et al., 2005) and the Muikamachi and Obirou faults (Watanabe et al., 2001). High-resolution common mid-point (CMP) seismic reflection data were acquired (Sato et al., 2005; Table 1) using a mini-vibrator (IVI, T-15000) with shot interval of $10 \mathrm{~m}$. The sweep signals $(10-100 \mathrm{~Hz})$ were recorded with $10 \mathrm{~Hz}$ geophones deployed at $10 \mathrm{~m}$ intervals and a multi-channel $(180 \mathrm{ch})$ digital telemetry system.

\subsection{Interpretation of the seismic data}

The seismic line across the Yoshiwara anticline (CMPs200 to 300), the Koyagaragawa syncline (CMPs500 to 600) and the Muikamachi fault (CMPs 700) from west to east (Figs. 1, 2 and 3). Along the seismic line, the late Miocene Toyagamine Formation and Pliocene Shiroiwa and Wanazu Formations distribute at the axial part of the Yoshiwara anticline (Yanagisawa et al., 1986) and the Uonuma Formation is cropping out on the flank of the anticline. About $100 \mathrm{~m}$ east from the eastern end of the seismic line, lower Miocene Jonai Group is exposed.

The obtained seismic section portray the asymmetric geometry of the Yoshiwara anticline with a steeper eastern 


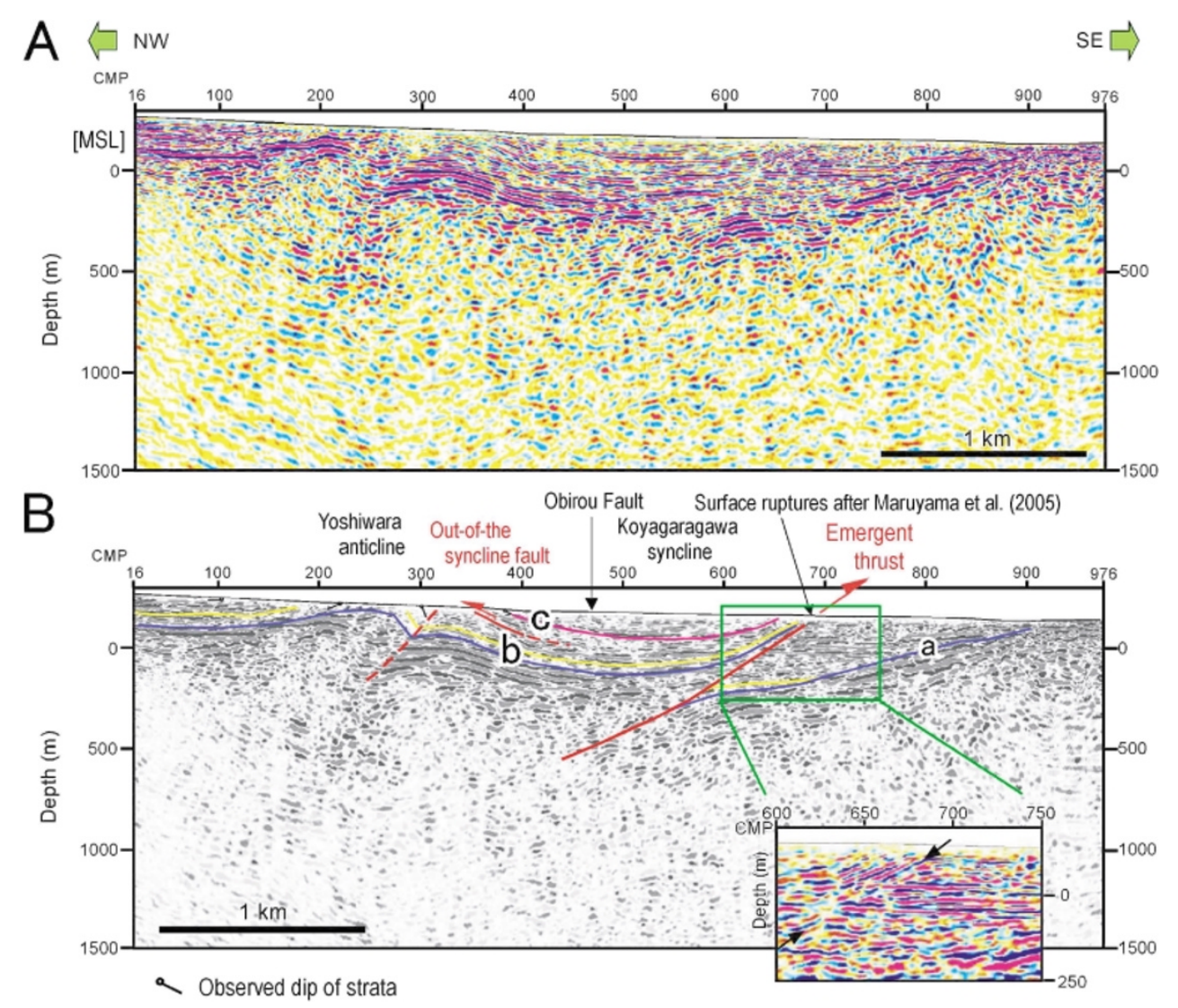

Fig. 2. (A) Migrated, depth-converted seismic section. The location of the seismic line is shown in Fig. 1B. (B) Geologic interpretation of the seismic section. No vertical exaggeration. See text for discussion of horizons "a", "b", and "c".

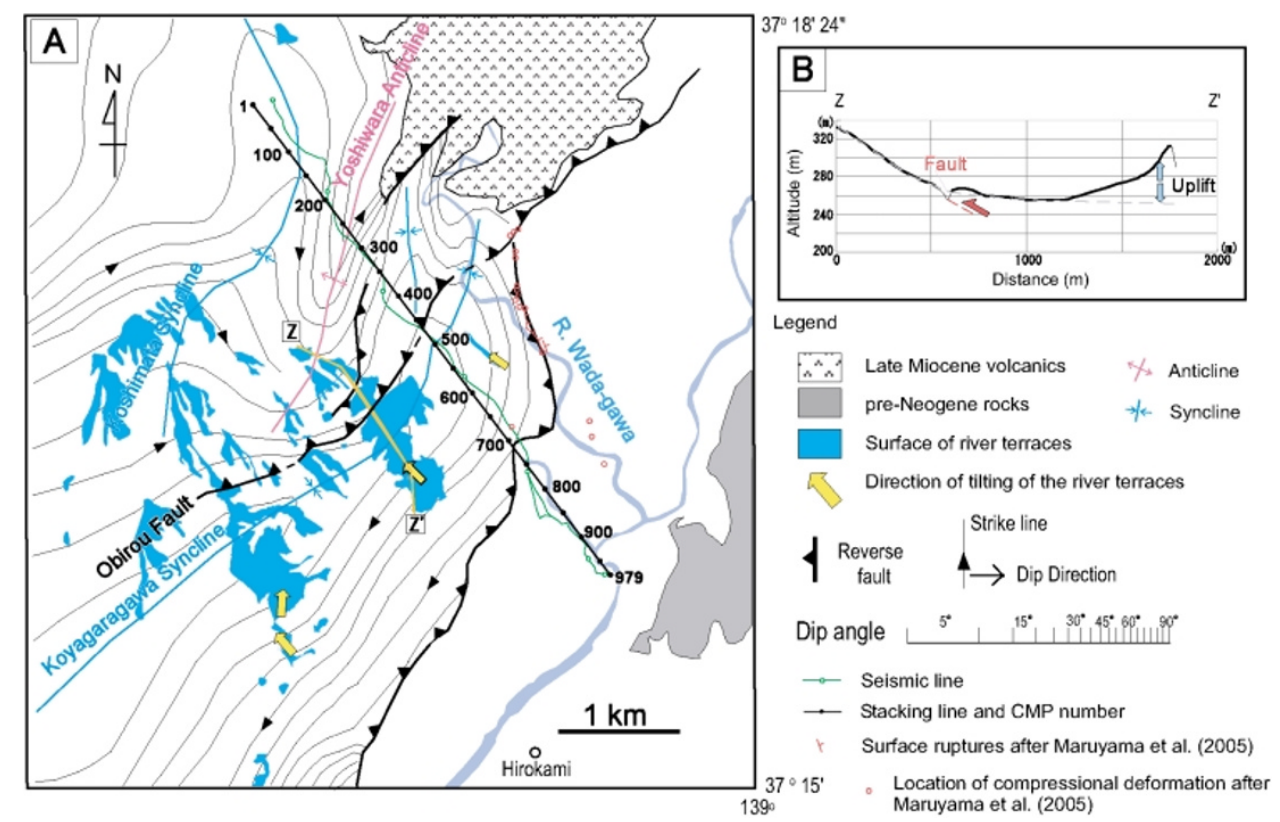

Fig. 3. Map showing the geologic structure and tectonic geomorphologic features around the seismic line. A) Strike-line map and distribution of river terraces. Contour represents $100 \mathrm{~m}$ interval in thickness. B) Topographic profile showing the deformation of river terraces along line $\mathrm{Z}-\mathrm{Z}^{\prime}$.

flank (Fig. 2). A gentle syncline, the Koyagaragawa syncline (Yanagisawa et al., 1986), is observed between CMPs 400 and 700 at depths shallower than $500 \mathrm{~m}$ below sea level. Footwall cutoffs apparent between CMP 480 and 700 on the seismic profile lie at the ground surface to $700 \mathrm{~m}$ depth in the Uonuma, Wanazu, and Shiroiwa Formation. Reflectors in the hanging wall of the thrust marked by the footwall cutoffs dip westward. We interpret these features as defining the highest-level, east vergent emergent thrust that breakthrough the ground surface. 


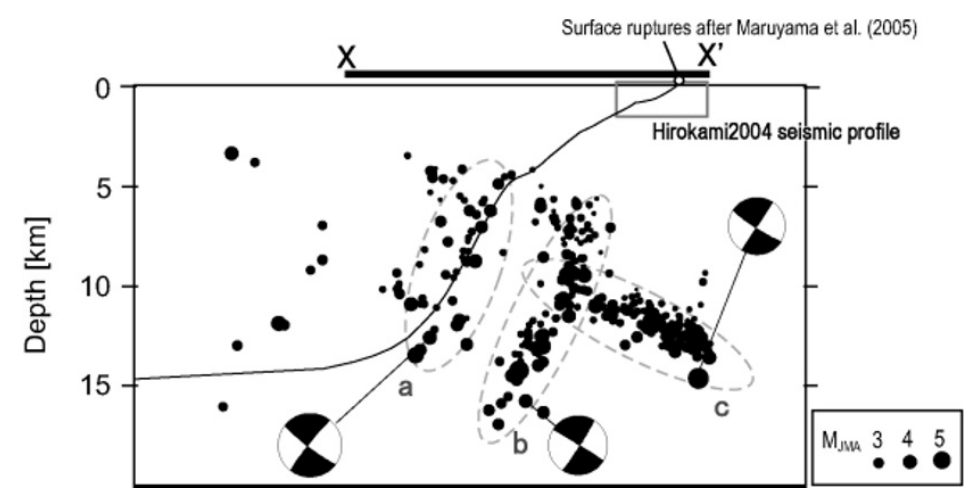

Fig. 4. Schematic diagram showing the relationship between the aftershock distribution and shallow crustal structure. The aftershock distribution is after Sakai et al. (2005). The colored circles are hypocenters of earthquakes recorded between October 24 and October 27 November 2004 . Only those hypocenters within $10 \mathrm{~km}$ of the profile are plotted. The location of line $\mathrm{X}-\mathrm{X}^{\prime}$ is shown in Fig. 1.

Based on correlation of reflectors on the seismic section with stratigraphic contacts of strata (Yanagisawa et al., 1986), horizon "a" and "b" are interpreted as the top of the middle Pliocene Shiroiwa Formation and late Pliocene Wanazu Formation, respectively. The horizon "c" is interpreted to be an unconformable boundary with the Uonuma Formation. Below horizon "a", the reflections are characterized by low frequency content and relatively large amplitudes. On the footwall side of the emergent thrust, geologic correlation of horizon "a" with surface features is obscured. Here, the horizon may correspond to the top of the late Miocene volcanics or an older unit.

\section{Discussion}

4.1 Structural relationship between the coseismic surface rupture, tectonic geomorphology, and active thrust imaged in the seismic section

The surface trace of the emergent thrust identified on the seismic section extends to CMP 700 at the surface (Fig. 2). This location is consistent with the site at which Maruyama et al. (2005) identified a short segment of surface rupture (CMP 680-710; Fig. 3). To the north, on the banks of the Wada-gawa River, a 400-m-long rupture has been reported (Maruyama et al., 2005; Fig. 3). Thus we confidently argue that these surface ruptures emerged during the 2004 MidNiigata earthquake sequence were generated by coseismic slip on the emergent thrust imaged on the seismic section.

Topographic profile across the $\mathrm{H}$ terraces clearly indicates that the northwest-facing fold scarp of the river terraces can be seen at the hanging wall of the emergent thrust, consistent with the underlying west-dipping strata. Synclinal axis at the base of the northwest-facing fold scarp is also consistent with that of the Koyagaragawa syncline (Fig. 3B). Small west-facing fault scarp indicated by the topographic profile is underlain by the out-of-the-syncline thrust imaged on the seismic section. The seismic line crosscuts the surface trace of fold scarps along the Obirou fault mapped by Watanabe et al. (2001) at CMP 460, below which the seismically imaged subsurface structure corresponds to the eastern limb of the Koyagaragawa syncline. The subsurface extension of the Obirou fault is marked by a synclinal axis that divides the forelimb strata of the Yoshiwara anticline.
The east-facing fold scarp on the $\mathrm{H}$ terraces in the eastern flank of the Yoshiwara anticline indicates that late Quaternary growth of the anticline. On the seismic section, the emergent thrust seem to be displaced younger sediments than the higher terrace deposits. Judging from the age of the displaced sediments, the Yoshiwara anticline and Obirou fault may be produced earlier than the emergent thrust. Such sequential eastward shift of the deformational front suggests that the geologic structures on the seismic section were probably formed by the single fault propagation processes.

\subsection{Geometry of the fault system associated with the main shock}

The distribution of aftershock hypocenters during October 24 to October 27 was determined by the Research Group for Urgent Aftershock Observation of the Earthquake Research Institute, University of Tokyo (Hirata et al., 2005; Sakai et al., submitted). The observed aftershock locations configure several faults, including the two west-dipping faults to have produced the main shock ("a" in Fig. 4) and the largest aftershock ("b" in Fig. 4), and a shallowly eastdipping fault associated with the $\mathrm{M}_{\mathrm{JMA}} 6.1$ earthquake of October 27 ("c" in Fig. 4). Focal mechanism for the main shock event based on body wave analysis (Yamanaka, 2004) contains a fault plane dipping $57^{\circ}$, consistent with the fault plane "a" inferred from its aftershock distribution dipping about $60^{\circ}$ (Fig. 4).

The upward projection of the fault plane " $b$ ", which generated the maximum aftershock, is located near the site where surface ruptures were observed. However, no seismicity was observed along the up-dip extension of the fault plane at depth shallower than $6 \mathrm{~km}$ (Hirata et al., 2005). The upper extension of the source fault "a" also shows no seismicity, but this part is marked low velocity structure due to the thick accumulation of sediments (Kato et al., 2005). However, the up-dip extension of the source fault of maximum aftershock, it is marked by high velocity area. Therefore, the lack of seismicity suggests that the possible up-dip extension of source fault " $b$ " did not rupture to the shallow part. Namely, the possible source fault which can generate the surface ruptures at the eastern rim of the Uonuma Hills is the one of the main shock ("a" in Fig. 4).

The geometry of the deeper extension of the emergent 
thrust along the northern extension of the Muikamachi fault has been examined by means of cross-section balancing of the geologic cross-section across the Uonuma Hills. The earliest stage of tectonic development in Fig. 5C corresponds to deposition of the tephra named NA13 (ca. 3.9 Ma) in the Ushigakubi Formations (Yanagisawa et al., 1986). The paleobathymetry during the deposition of NA13 indicates that the lower part of the Ushigakubi Formation in the western limb of the Higashiyama anticline was at outer sublittoral to upper bathyal depths (Yanagisawa et al., 1986). On the eastern limb of the Higashiyama anticline, the paleobathymetry of the NA13, which occurs there in the middle of the Ushigakubi Formation, is estimated to be outer sublittoral based on benthic fossils (Yanagisawa et al., 1986). This indicates that the paleobathymetry of NA13 was deeper to the west $(\sim 800 \mathrm{~m})$ than to the east $(\sim 150 \mathrm{~m})$. Given conservation of bed areas during deformation, we estimated appropriate restoration of deformed strata based on quantitative relationships between fault and fold geometry and the amount of slip on fault planes. Present thrust produce surface ruptures already emerged to the surface. Thus, forward modeling was carried out based on the fault-bend theory.

Our kinematic models suggest that the Higashiyama anticline and minor folds to the east are underlain by a single, upward-flattening thrust fault with several anticlinal and synclinal fault bends. Deeper 60 west-dipping ramp below the Higashiyama anticline is consistent well with the presumed fault plane that generated the main shock. Furthermore, shallower 30 west-dipping ramp appears to link with the emergent thrust imaged on the seismic section, and thus, the surface ruptures generated by this earthquake sequence. While further elucidating the relationship between the source fault and surface ruptures will require deep seismic profiling to obtain more detailed, crustal scale geometry of the fold-and-thrust belt.

\section{Conclusions}

High-resolution seismic reflection profiling was carried out across surface ruptures associated with the 2004 MidNiigata Prefecture earthquake. The resulting seismic reflection profile reveals an emergent thrust beneath the surface ruptures. Based on observed geologic structures, this emergent thrust is inferred to be the northern extension of the Muikamachi fault.

Taking into consideration the geometry of the fault responsible for the 2004 earthquake estimated from aftershock hypocenters and shallow subsurface structures revealed by the seismic reflection data, we have developed a two-dimensional model of the fault geometry. Forward modeling based on a balanced cross-section technique provides an upward flattening trajectory of a thrust that are consist of both the presumed fault plane that generated the main shock event and the location of the surface ruptures (Maruyama et al., 2005). Thus we concluded that the thrust fault model presented here are possibly responsible for the main shock event of this earthquake.

Acknowledgments. We thank to Tatsuya Ishiyama and Thomas Pratt for review. Their comments helped to improve our

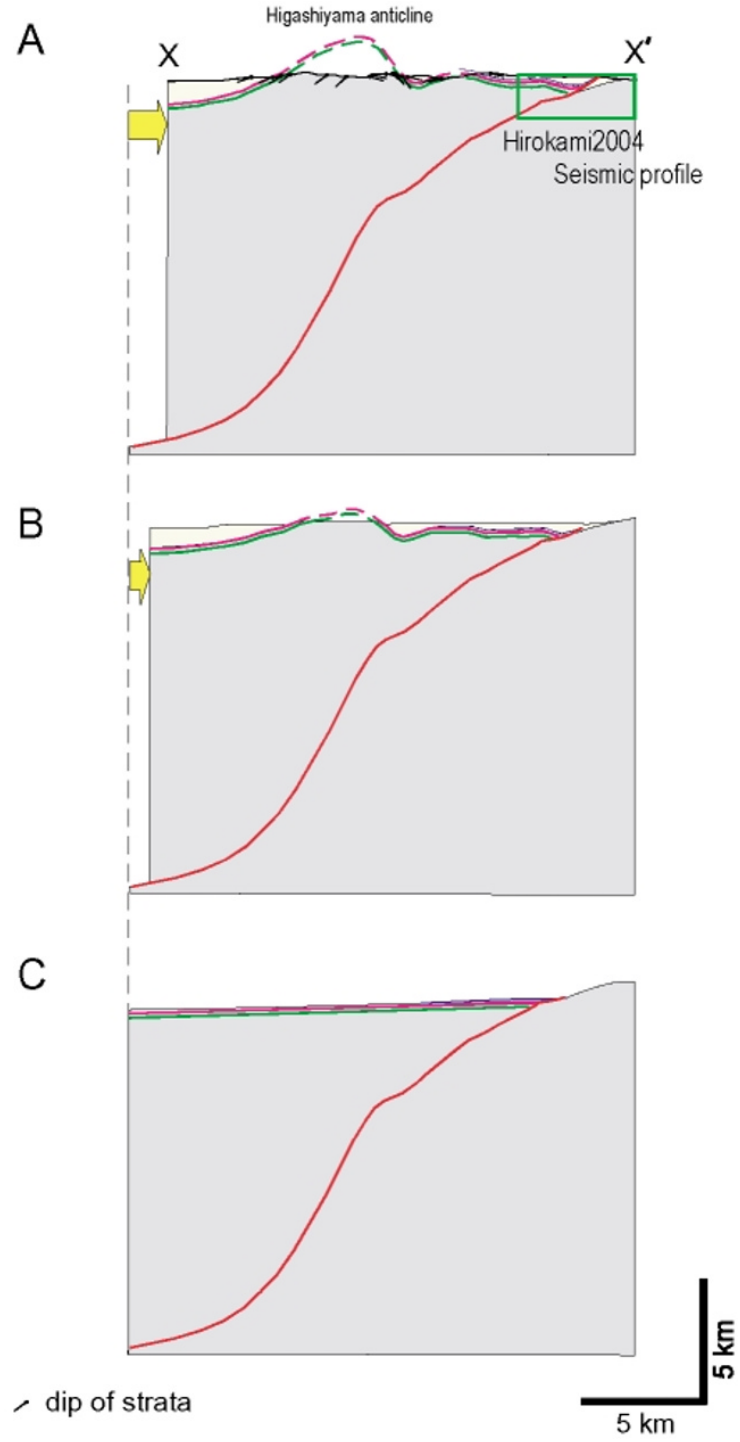

Fig. 5. Balanced geologic cross sections showing the geologic development of a transect across the Uonuma Hills. The location of the section is shown in Fig. 1 as $\mathrm{X}-\mathrm{X}^{\prime}$. The geologic information is after Yanagisawa et al. (1985) and Yanagisawa et al. (1986).

manuscript. We are grateful to the seismic crew of the Hirokami 2004 project and the Research Group for Urgent Aftershock Observation of the Earthquake Research Institute, University of Tokyo, for providing seismic data, and to Takaya Iwasaki and Naoshi Hirata for discussions. The seismic experiments were funded by Special Coordination Funds for Promoting Science and Technology provided by the Ministry of Education, Science, Culture and Sports.

\section{References}

Hirata, N., H. Sato, S. Sakai, A. Kato, and E. Kurashimo, Fault system of the 2004 Mid Niigata prefecture earthquake and its aftershocks, Landslides, 2(2), doi:10.1007/s10346-005-0050-8, 2005.

Ikeda, Y., T. Imaizumi, M. Togo, K. Hirakawa, T. Miyauchi, and H. Sato, Atlas of Quaternary thrust faults, Tokyo Univ. Press, 254 pp., 2002.

Kato, A., E. Kurashimo, N. Hirata, S. Sakai, T. Iwasaki, and T. Kanazawa, Imaging the source region of the 2004 mid-Niigata prefecture earthquake and the evolution of a seismogenic thrust-related fold, Geophys. Res. Lett., 2005 (in press).

Maruyama, T., Y. Fusejima, T. Yoshioka, and Y. Awata, Morphological characteristics of the surface rupture associated with the Mid Niigata Prefecture earthquake in 2004, Chishitsu News, 607, 9-12, 2005 (in Japanese). 
Niigata Prefectural Government, Geology of the Niigata Prefecture, with Geological Sheet Map at 1:200,000, Niigata Prefectural Government, 200 pp., 2000 (in Japanese).

Ohba (Seki), Y. and K. Kosaka, Active folding in Ojiya area, Niigata Prefecture-Possible tectonic change at 2.5-2 Ma Viewed from dipangles of strata, Proceedings of the institute of natural sciences Nihon University, 36, 111-116, 2001.

Sakai, S., N. Hirata, A. Kato, E. Kurashimo, T. Iwasaki, and T. Kanazawa, Multi-fault system of the 2004 Mid-Niigata Prefecture Earthquake and its aftershocks, Earth Planets Space, 57, this issue, 417-422, 2005.

Sato, H., The relationship between late Cenozoic tectonic events and stress field and basin development in northeast Japan, J. Geophys. Res., 99, 22261-22274, 1994.

Sato, H., N. Kato, T. Echigo, S. Ogino, M. Tateishi, S. Toda, H. Kato, S. Koshiya, T. Toyoshima, T. Ito, T. Imaizumi, S. Abe, N. Suzuki, E. Misawa, S. Oda, K. Kagohara, T. Koike, S. Akai, and K. Noda, High resolution seismic reflection profiling across the surface rupture associated with the 2004 Mid-Niigata Prefecture earthquake, central Japan: data acquisition and processing, Bull. Earthq. Res. Inst., 2005 (submitted) (in Japanese with English abstr.).

Tsutsumi, H. and R. S. Yeats, Tectonic setting of the 1971 Sylmar and 1994 Northridge earthquakes in the San Fernando Valley, California, Bull. Seismol. Soc. Am., 89, 1232-1249, 1999.
Watanabe, M., H. Tsutsumi, Y. Suzuki, H. Y. Kim, and N. Sato, Active fault map in urban area: Ojiya, Technical report of the Geographical Survey Institute, D.1, No. 388, 2001.

Yamanaka, Y., Mid-Niigata Prefecture earthquake $(\mathrm{Mj}$ 6.8) of October 23, 2004, EIC Seismological note, No. 154, http://www.eri.utokyo.ac.jp/sanchu/Seismo_Note/2004/EIC154.html., 2004.

Yamashita, N., Proposal of the Choshi-Kashiwazaki tectonic line, in The Island Arc and Ocean, edited by T. Hoshino and T. Aoki, pp. 179-191, Tokai Univ. press, 1970 (in Japanese).

Yanagisawa, Y., K. Chihara, Y. Suzuki, T. Uemura, K. Kodama, and T. Kato, Geology of the Tokamachi district, with Geological Sheet Map at 1:50,000, Geological Survey of Japan, 104 p., 1985 (in Japanese with English abstract).

Yanagisawa, Y., I. Kobayashi, K. Takeuchi, M. Tateishi, K. Chihara, and T. Kato, Geology of the Ojiya district, with Geological Sheet Map at 1:50,000, Geological Survey of Japan, 177 pp., 1986 (in Japanese with English abstract).

N. Kato (e-mail: naoko@eri.u-tokyo.ac.jp), T. Echigo, H. Sato, M. Tateishi, S. Ogino, S. Sakai, S. Toda, S. Koshiya, T. Ito, T. Toyoshima, T. Imaizumi, H. Kato, and S. Abe 